Article

\title{
Energy and Exergy Analyses on Seasonal Comparative Evaluation of Water Flow Cooling for Improving the Performance of Monocrystalline PV Module in Hot-Arid Climate
}

\author{
Ali Sohani ${ }^{1, *(\mathbb{D})}$, Mohammad Hassan Shahverdian ${ }^{1}$, Hoseyn Sayyaadi ${ }^{1}$ (D), Siamak Hoseinzadeh ${ }^{2, *(D)}$, \\ Saim Memon ${ }^{3, *(\mathbb{D})}$, Giuseppe Piras ${ }^{4}$ (D) and Davide Astiaso Garcia ${ }^{2}$ (D)
}

1 Laboratory of Optimization of Thermal Systems' Installations, Faculty of Mechanical Engineering-Energy Division, K.N. Toosi University of Technology, P.O. Box 19395-1999, No. 15-19, Pardis St., Mollasadra Ave., Vanak Sq., Tehran 1999-143344, Iran; mh.shahverdian@gmail.com (M.H.S.); sayyaadi@kntu.ac.ir (H.S.)

2 Department of Planning, Design, Technology of Architecture, Sapienza University of Rome, Via Flaminia 72, 00196 Rome, Italy; davide.astiasogarcia@uniroma1.it

3 London Centre for Energy Engineering, Solar Thermal Vacuum Engineering Research Group School of Engineering, London South Bank University, London SE1 0AA, UK

4 Department of Astronautics, Electrical and Energy Engineering (DIAEE), Sapienza University of Rome, Via Eudossiana, 18, 00184 Rome, Italy; giuseppe.piras@uniroma1.it

* Correspondence: asohani@mail.kntu.ac.ir (A.S.); siamak.hosseinzadeh@uniroma1.it (S.H.); S.Memon@lsbu.ac.uk (S.M.); Tel.: +44-(0)-20-7815-7510 (S.M.)

Citation: Sohani, A.; Shahverdian, M.H.; Sayyaadi, H.; Hoseinzadeh, S.; Memon, S.; Piras, G.; Astiaso Garcia, D. Energy and Exergy Analyses on Seasonal Comparative Evaluation of Water Flow Cooling for Improving the Performance of Monocrystalline PV Module in Hot-Arid Climate. Sustainability 2021, 13, 6084. https://doi.org/10.3390/su13116084

Academic Editors: Alessandro Franco and Marc A. Rosen

Received: 21 April 2021

Accepted: 26 May 2021

Published: 28 May 2021

Publisher's Note: MDPI stays neutral with regard to jurisdictional claims in published maps and institutional affiliations.

Copyright: (c) 2021 by the authors. Licensee MDPI, Basel, Switzerland. This article is an open access article distributed under the terms and conditions of the Creative Commons Attribution (CC BY) license (https:/ creativecommons.org/licenses/by/ $4.0 /)$.

\begin{abstract}
Solar irradiation in hot-arid climatic countries results in increased temperatures, which is one of the major factors affecting the power generation efficiency of monocrystalline photovoltaic (PV) systems, posing performance and degradation challenges. In this paper, the efficiency of a water-flow cooling system to increase the output of a monocrystalline PV module with a rated capacity of $80 \mathrm{~W}$ is studied from both energy and exergy perspectives. The energy and exergy tests are performed for each season of the year, with and without cooling. The energy and exergy efficiencies, as well as the commodity exergy values, are used to compare the photovoltaic device with and without cooling. The findings are based on the experimental data that were collected in Tehran, Iran as an investigated case study in a country with a hot-arid climate. The findings show that when water-flow cooling is used, the values of the three efficiency metrics change significantly. In various seasons, improvements in regular average energy efficiency vary from $7.3 \%$ to $12.4 \%$. Furthermore, the achieved increase in exergy efficiency is in the $13.0 \%$ to $19.6 \%$ range. Using water flow cooling also results in a $12.1 \%$ to $18.4 \%$ rise in product exergy.
\end{abstract}

Keywords: hot-arid climate; energy analysis; exergy analysis; water flow cooling; monocrystalline PV module

\section{Introduction}

An affordable solar (photovoltaics (PV)) technology will be of significance in hot-arid developing countries using monocrystalline PV panels [1], which are a reality of transitioning from non-renewable to renewable energy sources [2-4]. Some of the absorbed solar irradiation is converted into electricity in a PV module, which operates on the principle of a semiconductor [5-7], while the remainder is either dissipated into the surroundings or absorbed by the module itself [8-10]. The absorbed energy raises the surface cumulative heat-induced temperature of the PV module, which decreases its output V-I (VoltageCurrent) performance [11-14]. As a result, controlling the temperature of a PV module is critical, which can be accomplished through a variety of cooling techniques [14-17]. Either passive cooling or active cooling can be used [18-22]. The active cooling method employs 
water or nanofluid cooling methods [23], whereas the passive system employs thermoelectric Peltier modules [24] or vacuum insulation [25-27] to minimize the cumulative surface heat induction on PV panels.

Active techniques can provide better performance, and water-flow cooling (WFC) is one of the most cost-effective methods [28] for active cooling of a PV panel. The reasons for this are diverse, but WFC can habitually provide a rationale such as: obtaining a more uniform surface temperature distribution on the PV panel, which aids in the extension of the system's lifetime; increasing the light absorption potential by 2.0 to 3.6 percent because water's refractive index (1.3) is between that of air (1.0) and glass (1.5) [29]; because water has a relatively better heat absorbency and because the water and the module are in direct contact, this method can lower the working temperature of the module more than other methods; and keeping the module clean to reduce the negative effects of dust on energy output and to be environmentally friendly, with no risk of toxic chemicals leaking into the environment. These advantages have prompted a number of studies on the use of WFC to improve the performance of PV modules. Table 1 summarizes numerous studies conducted in this field, and evaluates two investigative matters for them, which could be regarded as a gap in previous investigations. These are the two investigative matters:

- First, a thorough exergy analysis, including investigating parameters such as product exergy and exergy efficiency, has not been reported in the literature within the context of water-flow cooling. It is worth mentioning that there have been some investigations, such as those of Abadeh et al. [30], Sardarabadi et al. [31], Khanjari et al. [32], Chow et al. [33], Alnaqi et al. [34], and Afrand et al. [35], in which exergy analysis was carried out for a PV system. However, the investigated systems in those studies were not similar to the considered system of this research work. In addition, the exergy analysis was usually done at either the standard test condition, or the peak temperature and radiation time, or only for a single sample day, which means the seasonal analysis has not been conducted.

- Second, a seasonal comparison study on a hot-arid climatic country, such as Iran, of conditions with and without cooling, has not yet been reported. To the best of the authors' knowledge, there was only one study by Shahverdian et al. [29], in which seasonal analysis of a PV system with water-flow cooling has been performed. However, in that study [29], neither energy nor exergy efficiency was considered.

As a result, the current study is carried out, in which the following investigative matters are considered novelties, to the best of the authors' knowledge.

- Exergy analysis is carried out in detail by utilizing product exergy and exergy efficiency as the two main essential parameters for exergy analysis.

- A detailed study of the PV system on a sample day from each season of the year to provide the ability to compare the values on different seasons of the year, with Iran as a case study for a hot-arid developing country.

- The results are presented for conditions both with and without cooling. The $80 \mathrm{~W}$ monocrystalline PV module is selected, and the recorded experimental data are used as the input of modeling. In addition to product exergy and exergy efficiency, the energy efficiency is studied as another key indicator of a PV system. 
Table 1. A checklist evaluating the studies carried out in the field based on the two items which are considered as the gap in previous investigations.

\begin{tabular}{cccc}
\hline Study & Year & $\begin{array}{c}\text { Was a Detailed } \\
\text { Exergy Analysis } \\
\text { Conducted? }\end{array}$ & $\begin{array}{c}\text { Was a Seasonal } \\
\text { Comparative Study } \\
\text { Performed? }\end{array}$ \\
\hline Kim et al. [36] & 2011 & No & No \\
Prudhvi and Sai [37] & 2012 & No & No \\
Raval et al. [38] & 2014 & No & No \\
Tiwari et al. [39] & 2015 & No & No \\
Nižetić et al. [40] & 2016 & No & No \\
Basrawi et al. [41] & 2018 & No & No \\
Edaris et al. [42] & 2018 & No & No \\
Chen et al. [43] & 2019 & No & No \\
Benato and Stoppato [44] & 2019 & No & No \\
Mah et al. [45] & 2019 & No & No \\
Sainthiya and Beniwal [46] & 2019 & No & No \\
Tashtoush and Oqool [47] & 2019 & No & Yos \\
Luboń et al. [48] & 2020 & No & No \\
da Silva et al. [49] & 2021 & No & Yes \\
Shahverdian et al. [29] & 2021 & No & Yes \\
Javidan and Moghadam [50] & 2021 & & \\
The present research work & 2021 & &
\end{tabular}

\section{Materials and Methods}

\subsection{Experimental Materials and Methods}

The hot-arid climate of Tehran, Iran, was selected for the energy and exergy analyses. Tehran is the capital of Iran and one of the world's largest cities, with profound solar irradiation potential, since the average annual solar irradiation obtained on horizontal surfaces is monumental. Rising electricity demand in this region, combined with a high level of pollutants in the air, has prompted policymakers to introduce PV technology in Tehran, and many schemes have been initiated in recent years to raise the city's installed capacity of PV modules.

The current methods can be used for various styles and sizes of PV modules worldwide. The widely available monocrystalline PV module in Iran is selected for experimental study, having the following specifications [51]:

- module type: YL80C-18b,

- number of cells connected together in series: 36,

- length, width, and thickness: $0.770 \mathrm{~m}, 0.664 \mathrm{~m}$, and $0.025 \mathrm{~m}$, respectively,

- nominal capacity for power production: $80 \mathrm{~W}$,

- nominal energy efficiency: 0.194,

- maximum power point and short-circuit current values: 4.26 and $4.51 \mathrm{~A}$, respectively,

- maximum power point and open-circuit voltage values: $18.79 \mathrm{~V}$ and $23.07 \mathrm{~V}$, respectively,

- nominal operating cell temperature: $47^{\circ} \mathrm{C}$,

- temperature coefficients for the maximum power, open-circuit voltage, and shortcircuit current: $-0.40 \% . \mathrm{K}^{-1},-0.35 \% . \mathrm{K}^{-1}$, and $+0.06 \% . \mathrm{K}^{-1}$, respectively.

An experimental setup as depicted in Figure 1 was used to collect the results. The $\mathrm{PV}$ module was mounted on a fixed steel frame at a tilt angle of $35.7^{\circ}$, which is the recommended tilt angle [52] for maximizing solar irradiation on the surface of a PV system. This setup's configuration, materials, and measurement instruments were identical to that implemented in the research team's previous report [29]. Since all the details have been completely given in [29], in order to not make this paper too long, please refer to that study for more information. This investigation's experiments took place on 5 February, 5 May, 5 August, and 5 November 2020. The indicated days are the middle of winter, spring, summer, and fall months in the city of Tehran, Iran. 


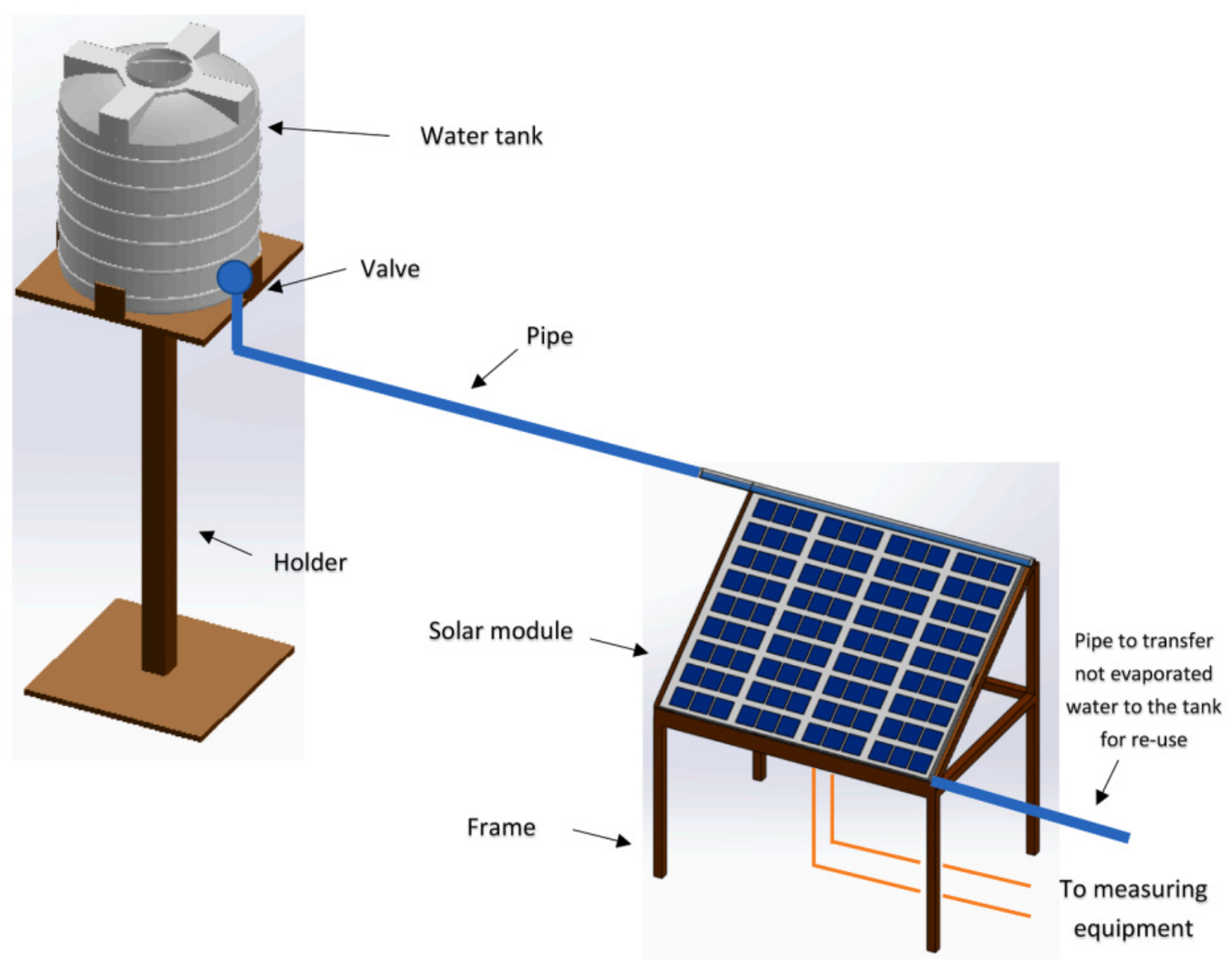

Figure 1. The experimental setup employed in this study to record data [29].

Using a similar method to the previously conducted studies in the field of waterflow cooling for improving the performance of PV technologies, including [29] in the investigated system, the water that has not evaporated is collected in a bottom tank. Then, during the midnight hours when there is extra electricity produced by the national power grid, the collected water was sent to the upper tank by employing a pump. In this way, the optimum conditions for producing and consuming electricity by the system could be achieved. Therefore, there is no need to subtract the pump power variable to determine the net output from the PV panel.

\subsection{Modeling Approach}

The first parameter which is calculated, based on the measured data, is the efficiency. The energy efficiency $(\eta)$ can be determined from Equation (1) [53]:

$$
\eta=\frac{P}{G A}=\frac{V I}{G A}
$$

where $P, V, I$, and $G$ are the produced power, voltage, and current of the module, and the received solar radiation, respectively. These were all measured by the measurement devices. Moreover, $A$ denotes the area of the module, which is a known parameter.

In addition to the energy efficiency, the product's exergy values will be compared. Exergy is defined as the maximum possible achievable work from a certain amount of 
energy [54]. The product exergy for a PV system without and with cooling ( $E_{x_{P V}}^{\text {product }}$ and $\left.E_{x_{P V W F C}}^{\text {product }}\right)$ are obtained by Equations (2) and (3), respectively:

$$
\begin{gathered}
\dot{E}_{x_{P V}}^{\text {product }}=\dot{E}_{x_{\text {power }}}=P \\
\dot{E}_{x_{P V W F C}}^{\text {product }}=\dot{E}_{x_{\text {power }}}+\Delta \dot{E}_{x_{\text {water }}}=P+\Delta \dot{E}_{x_{\text {water }}}=P+\dot{E}_{x_{\text {water }, \text { out }}}-\dot{E}_{x_{\text {water }, \text { in }}}
\end{gathered}
$$

where $P, \dot{E}_{x_{\text {water, out }}}$, and $\dot{E}_{x_{\text {water }, \text { in }}}$ represent the produced power and the exergy of the water exiting and entering the surface of the module, respectively. The exergy values for the cooled PV module show that there is a potential for this system to deliver energy (hot water). The exergy and energy values for the produced power of the module, which is the amount of energy in the form of work, are equal [54]. Therefore:

$$
\dot{E}_{x_{\text {power }}}=P
$$

In addition, the changes in the exergy of water flowing on the surface of the module is equal to the variation of the physical exergy [54]. As a result, and since the value of evaporated water is significantly smaller than the amount of inlet water flow for cooling the module $\left(\dot{m}_{\text {water, in }}\right), \Delta \dot{E}_{x_{\text {water }}}$ could be expressed in the form of Equation (5):

$$
\Delta \dot{E}_{x_{\text {water }}}=\dot{E}_{x_{\text {water }, \text { out }}}-\dot{E}_{x_{\text {water }, \text { in }}}=\dot{m}_{\text {water, } \text {, }}\left\{h_{\text {water }, \text { out }}-h_{\text {water, in }}-T_{0}\left(s_{\text {water }, \text { out }}-s_{\text {water, in }}\right)\right\}
$$

where $h$ and $s$ denote the enthalpy and entropy, respectively. The pressure of both water streams is equal to the atmospheric pressure. Consequently, by knowing the temperatures of the inlet and outlet water from measurements, both mentioned $h$ and $s$ could be determined from thermodynamic tables. Knowing the product exergy for the PV system with and without cooling, the exergy efficiency $(\varepsilon)$ is calculated based on Equation (6):

$$
\varepsilon=\frac{\dot{E}_{x}^{\text {product }}}{\dot{E}_{x_{\text {solar }}}}
$$

where $\dot{E}_{x}^{\text {product }}$ is the product exergy of the system. $\dot{E}_{x_{\text {solar }}}$ also shows the exergy of the received solar radiation, which is computed from Equation (7) [55]:

$$
\dot{E}_{x_{\text {solar }}}=(1-\beta) A G\left[1-\frac{4}{3}\left(\frac{T_{a}}{T_{s}}\right)+\frac{1}{3}\left(\frac{T_{a}}{T_{s}}\right)^{4}\right]
$$

where, $\beta, T_{a}$, and $T_{s}$ are packing factor, ambient temperature, and the temperature of the surface of the sun, respectively. It should be noted that the sun's surface temperature, i.e., $T_{S}$ is required to determine the exergy of the received solar radiation. The exergy of the received solar radiation is defined as the maximum achievable work that could be obtained by utilizing a reversible heat engine between the sun, with the temperature of $T_{s}$ and ambient heat, with the temperature of $T_{a}$. Since the generated work of a reversible (Carnot) heat engine which works between $T_{s}$ and $T_{a}$ is a function of $\frac{T_{a}}{T_{s}}$ [54], this term, and consequently, $T_{s}$, appear in Equation (7), which is used to determine the exergy of the received solar radiation. More details can be found in [55].

Here are the steps leading to obtaining the results of this study, by which the adopted technologies are evaluated:

1. Initially, the voltage and current are determined using the multimeter.

2. Power is then obtained by multiplication of the two parameters determined in step 1 .

3. After that, the solar meter is employed, and the solar radiation is calculated.

4. Next, the energy efficiency of the system is computed from Equation (1). The value of the module area, which is needed to calculate energy efficiency, is extracted from the catalog. 
5. The calculation procedure is followed by obtaining the product exergy of the system. For this purpose, the temperature values of inlet and outlet water are measured from the experiments.

6. Subsequently, the exergy of the received solar radiation is determined by Equation (7).

7. Finally, by knowing both the product exergy and exergy of the received solar radiation, the exergy efficiency is found through Equation (6).

The steps are also presented in the process flow chart of Figure 2.

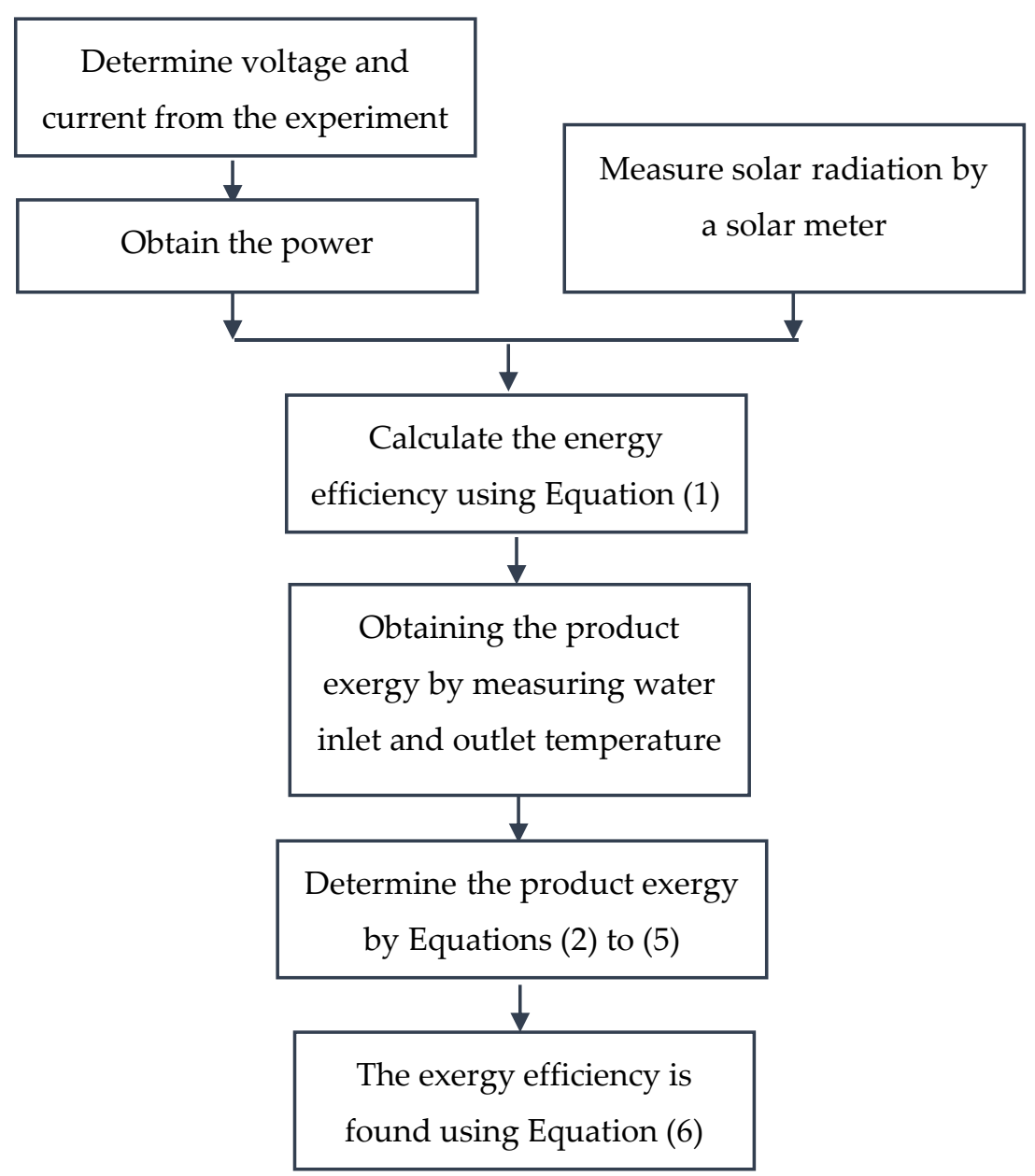

Figure 2. Flow chart of the steps leading to the evaluation of the investigated system.

\section{Results and Discussion}

As the first important performance criterion of the system which is investigated here, the daily average of energy efficiencies of a PV system with and without cooling are reported in Figure 3. This demonstrates that for the PV system without cooling, $\eta_{\text {daily }}$ varies from 0.143 in summer to 0.169 in winter, while spring and fall have close values of $\eta_{\text {daily }}$ together, which are 0.158 and 0.159 , respectively. 


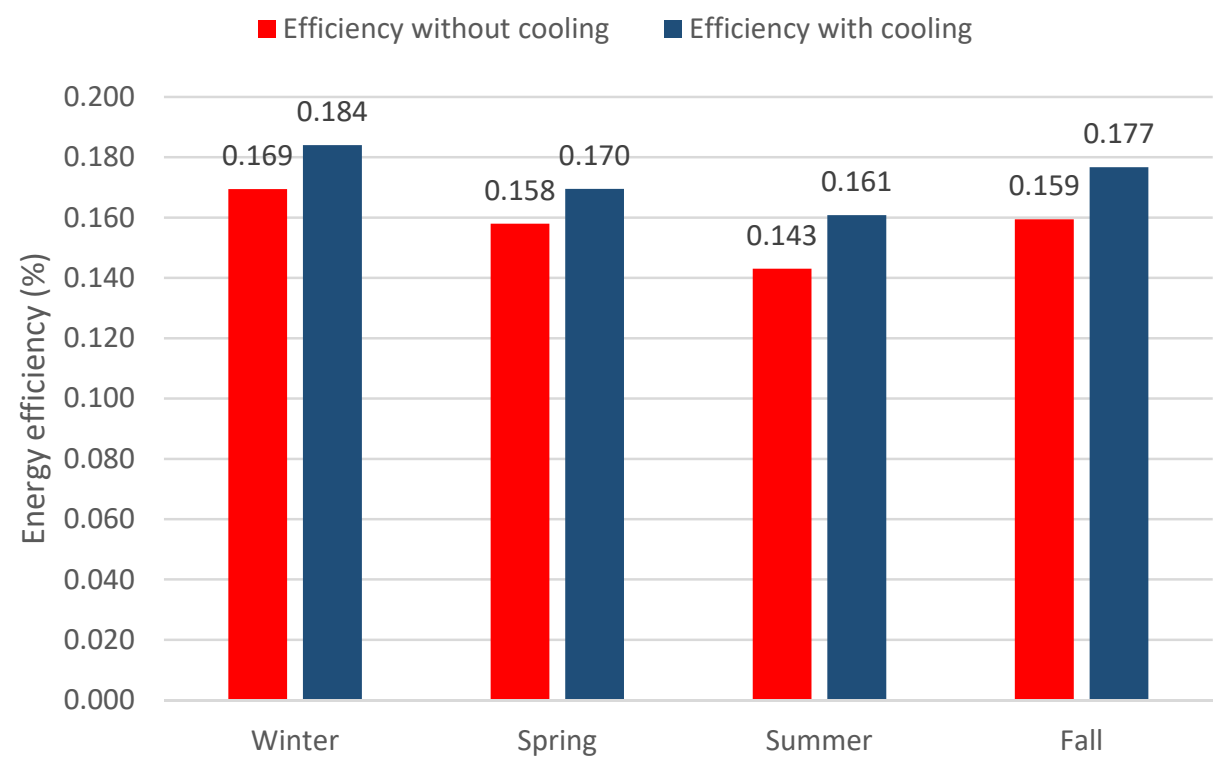

Figure 3. Seasonal comparison of the daily average energy efficiencies of PV system with and without cooling.

Water-flow cooling for a PV system enhances the energy efficiency significantly for all the investigated days, as shown in Figure 2 . In this case, $\eta_{\text {daily }}$ is in the range of 0.161 to 0.184 . The achieved enhancements compared to PV without a cooling system are $8.6 \%$, $7.3 \%, 12.4 \%$, and $10.9 \%$ for winter, spring, summer, and fall days, respectively. This is taken into account as a large improvement to the energy efficiency of a PV system.

Another parameter which is investigated here is the product exergy. Figure 4 shows the daily average values in different season of the year. On the selected sample winter day, $E_{x_{\text {daily }}}^{\text {product }}$ is $42.9 \mathrm{~W}$ for PV system without cooling, which is increased to $50.3 \mathrm{~W}$ by applying the water-flow cooling. This shows an improvement of $17.5 \%$. On the selected spring day, the obtained improvement of $E_{x_{d a i l y}}^{\text {product }}$ is $12.1 \%$, where PV systems with and without cooling offer the product exergy values of $50.6 \mathrm{~W}$ and $45.2 \mathrm{~W}$, respectively.

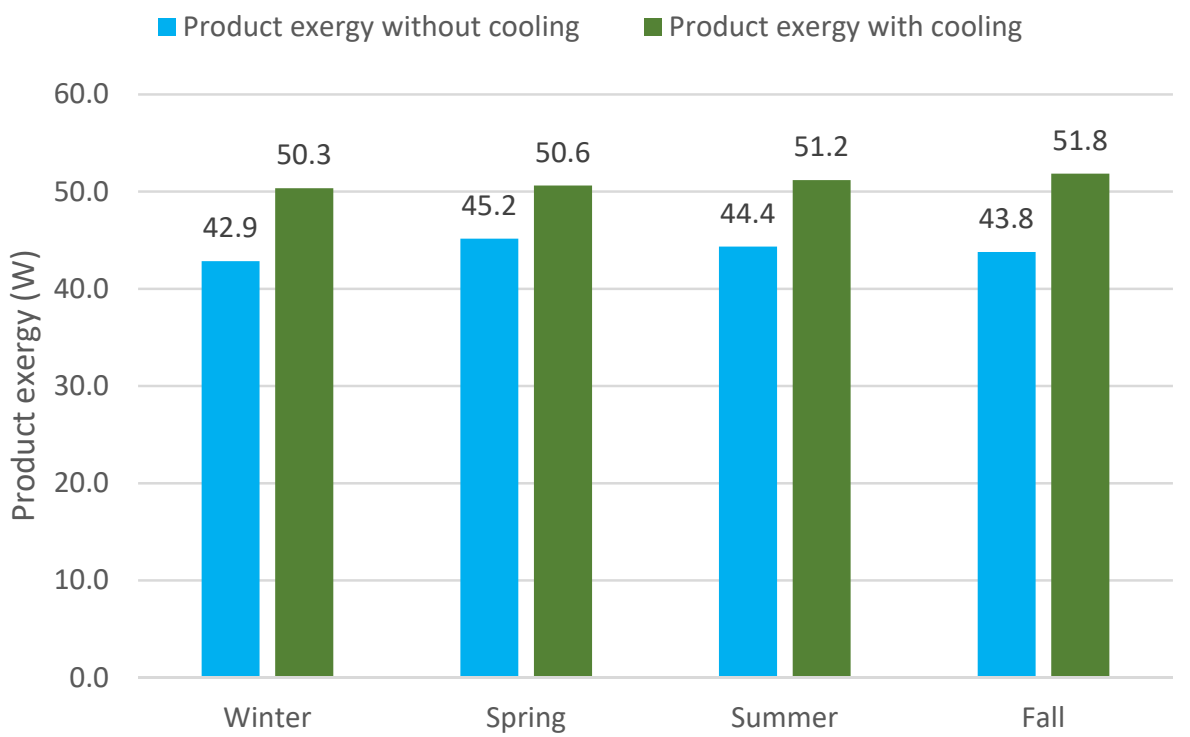

Figure 4. Seasonal comparison of daily average product exergy of the PV system with and without cooling. 
The improvement in $E_{x_{\text {daily }}}^{\text {product }}$ for the summer day is between spring and winter days. For this day, the values of $E_{x_{\text {daily }}}^{\text {product }}$ for with and without cooling are $51.2 \mathrm{~W}$ and $44.4 \mathrm{~W}$, respectively, which indicates an improvement of $15.4 \%$. With the value of $18.4 \%$, the highest seasonal increase in $E_{x_{\text {daily }}}^{\text {product }}$. when applying water flow cooling is also achieved in fall, in which $E_{x_{\text {daily }}}^{\text {product }}$ with and without cooling systems are equal to $51.8 \mathrm{~W}$ and $43.8 \mathrm{~W}$, respectively.

To clarify, the water flow and power exergy gain values because of utilizing the waterflow cooling in different seasons, as reported in Figure 5. As Figure 5 demonstrates, in the colder seasons of the year, i.e., winter and fall, whose representing months are February and November, the water flow exergy gain is more than the power exergy increase. Nonetheless, on the sample days on May and August, which are in spring and summer, the contribution of power exergy gain is much greater than the increase in the water exergy increase. Taking a more precise look at Figure 5 shows that the variation range of power exergy gain is narrow, which is from 3.4 to $4.3 \mathrm{~W}$. The exergy gain values for water, however, experience more extreme changes. The minimum water exergy gain is observed on the spring day, which is equal to $2.1 \mathrm{~W}$. With the value of $4.3 \mathrm{~W}$, which is more than two times higher than the minimum value, the maximum water exergy gain is seen for the winter day. The bigger water exergy gain values for the fall and winter days comes from the fact that the temperature difference between the inlet water and PV for these two indicated days is greater.

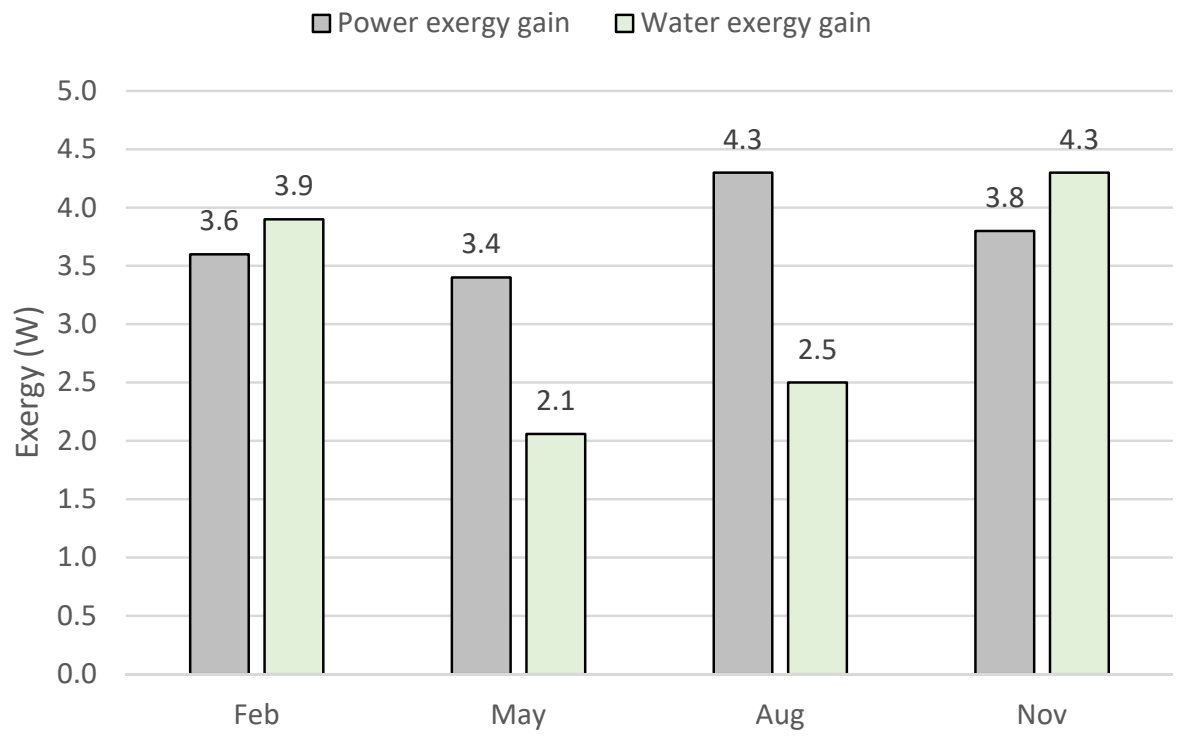

Figure 5. The water flow and power exergy gain values because of utilizing water flow cooling.

The values of exergy efficiency for different seasons are compared in Figure 6. Figure 6 shows that among the investigated days, the fall day has the highest potential to increase $\varepsilon_{\text {daily }}$ by applying water-flow cooling. On that day, $\varepsilon_{\text {daily }}$ jumps from 0.284 without cooling conditions to 0.340 in the cooling mode, which shows the great enhancement of $19.6 \%$. The winter day's increase by $19.3 \%$ is in second place after the fall day. On the daily average basis, the exergy efficiency rises from 0.301 to 0.359 . 


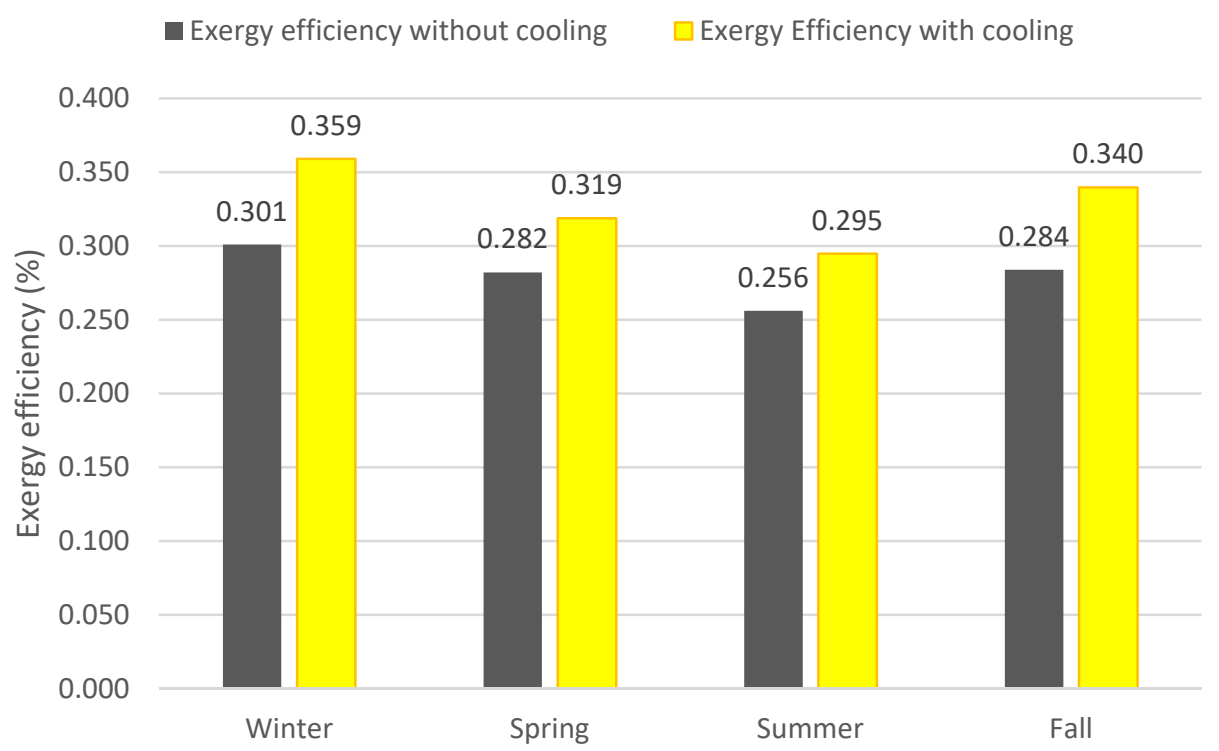

Figure 6. Seasonal comparison of the daily average exergy efficiencies of PV system, with and without cooling.

Summer and fall days are in the next ranks by offering 15.1 and $13.0 \%$, which are both considerable. When there is no cooling, the values of $\varepsilon_{\text {daily }}$ are 0.256 and 0.282 . Taking advantage of water-flow cooling leads to obtaining $\varepsilon_{\text {daily }}$ of 0.295 and 0.319 , respectively.

\section{Conclusions}

The measurements were performed on the installed PV device regarding the regular average energy and exergy efficiencies, as well as the product exergy, as the main performance indicators of the system on the sample days of winter, spring, summer, and fall, to allow for a seasonal comparative analysis. The findings are seen with and without cooling conditions. An $80 \mathrm{~W}$ monocrystalline PV module was chosen, and the experimental data collected during the experiments in Tehran, Iran, were used as the input for the modeling. The findings showed that utilizing water-flow cooling had a significant potential to improve any of the examined parameters. In various seasons of the year, the levels of improvement in energy quality, exergy efficiency, and product exergy are $7.3 \%$ to $12.4 \%$, $13.0 \%$ to $19.6 \%$, and $12.1 \%$ to $18.4 \%$, respectively. Furthermore, the sample summer day has the largest opportunity for raising energy efficiency, while the sample fall day has the greatest improvement in product exergy and exergy efficiency.

Greater improvement in exergy efficiency, compared to the energy increase, because of using a water-flow cooling system for a PV module, showed that there is room for enhancing the system performance. In the current water-flow cooling systems for PV modules, the water is returned to a tank. However, the conducted exergy analysis demonstrated that the water could be used in water-heating systems after flowing over the surface of the module. As the additional graph for the exergy gains showed, the amount of water exergy gain was considerable throughout all the seasons. This gain, which is taken into account as a suggestion for modification of the system, leads to higher efficiency in water-flow cooling systems for PV modules.

The measuring devices in this study were utilized in such a way that they could measure the generated power of the module, as well as the PV working temperature and water-in and water-out temperatures. Therefore, measuring the exact share of increasing light absorption and cooling in enhancing the performance of the system was not possible. Further study could be made by employing a simulation approach to find the percentages and explore this in detail. 
Author Contributions: Conceptualization, A.S. and M.H.S.; data curation, A.S. and M.H.S.; formal analysis, A.S., M.H.S., S.H. and S.M.; funding acquisition, A.S. and S.H.; investigation, A.S., M.H.S., S.H. and S.M.; methodology, M.H.S.; project administration, S.M., H.S., G.P. and D.A.G.; resources, A.S., M.H.S. and D.A.G.; software, A.S.; supervision, H.S., S.M., G.P. and D.A.G.; validation, A.S., M.H.S. and S.H.; visualization, S.M.; writing-original draft, A.S., M.H.S. and S.M.; writing-review \& editing, H.S., S.H., S.M. and G.P. All authors have read and agreed to the published version of the manuscript.

Funding: This research received no external funding.

Institutional Review Board Statement: Not applicable.

Informed Consent Statement: Not applicable.

Data Availability Statement: Not Applicable.

Acknowledgments: The authors would like to express their appreciation for the international research collaboration between the UK, Italy, and Iran in Renewable Energy.

Conflicts of Interest: The authors declare no conflict of interest.

\section{Nomenclature}

$\begin{array}{ll}\text { Symbols } & \text { Description (unit) } \\ A & \text { Module area }\left(\mathrm{m}^{2}\right) \\ \dot{E}_{x} & \text { Exergy rate } \\ G & \text { Irradiance }\left(\mathrm{W} \cdot \mathrm{m}^{-2}\right) \\ h & \text { Enthalpy }\left(\mathrm{kJ} \cdot \mathrm{kg}^{-1}\right) \\ I & \text { Current }(\mathrm{A}) \\ \dot{m} & \text { Mass flow rate }\left(\mathrm{kg} \cdot \mathrm{s}^{-1}\right) \\ P & \text { Power }(\mathrm{W}) \\ s & \text { Enthalpy }\left(\mathrm{kJ} \cdot \mathrm{kg}^{-1} \cdot \mathrm{K}^{-1}\right) \\ T & \text { Temperature }(\mathrm{K}) \\ V & \text { Voltage }(\mathrm{V}) \\ \text { Greek Symbols } & \text { Description (unit) } \\ \beta & \text { The packing factor }\left(\% \cdot \mathrm{K}^{-1}\right) \\ \varepsilon & \text { Exergy efficiency } \\ \eta & \text { Energy efficiency } \\ \text { Subscripts } & \text { Description } \\ 0 & \text { Dead-state condition, which is ambient condition for the investigated case. } \\ a & \text { Ambient } \\ \text { ex } & \text { Exergy } \\ \text { in } & \text { Inlet } \\ \text { power } & \text { Power } \\ \text { s } & \text { The surface of sun } \\ \text { solar } & \text { Solar } \\ \text { out } & \text { Outlet } \\ \text { water } & \text { Water } \\ & \end{array}$

\section{References}

1. Sohani, A.; Sayyaadi, H.; Moradi, M.H.; Nastasi, B.; Groppi, D.; Zabihigivi, M.; Astiaso Garcia, D. Comparative study of temperature distribution impact on prediction accuracy of simulation approaches for poly and mono crystalline solar modules. Energy Convers. Manag. 2021, 239, 114221. [CrossRef]

2. Yağlı, H.; Karakuş, C.; Koç, Y.; Çevik, M.; Uğurlu, İ; Koç, A. Designing and exergetic analysis of a solar power tower system for Iskenderun region. Int. J. Exergy 2019, 28, 96-112. [CrossRef]

3. Ustun, I.; Karakus, C.; Yagli, H. Empirical models for estimating the daily and monthly global solar radiation for Mediterranean and Central Anatolia region of Turkey. Int. J. Glob. Warm. 2020, 20, 249-275. [CrossRef]

4. Fardi Asrami, R.; Sohani, A.; Saedpanah, E.; Sayyaadi, H. Towards achieving the best solution to utilize photovoltaic solar panels for residential buildings in urban areas. Sustain. Cities Soc. 2021, 71, 102968. [CrossRef]

5. Loferski, J.J. Theoretical considerations governing the choice of the optimum semiconductor for photovoltaic solar energy conversion. J. Appl. Phys. 1956, 27, 777-784. [CrossRef] 
6. Abd Elaziz, M.; Thanikanti, S.B.; Ibrahim, I.A.; Lu, S.; Nastasi, B.; Alotaibi, M.A.; Hossain, M.A.; Yousri, D. Enhanced Marine Predators Algorithm for identifying static and dynamic Photovoltaic models parameters. Energy Convers. Manag. 2021, 236, 113971. [CrossRef]

7. Gorjian, S.; Ebadi, H.; Trommsdorff, M.; Sharon, H.; Demant, M.; Schindele, S. The advent of modern solar-powered electric agricultural machinery: A solution for sustainable farm operations. J. Clean. Prod. 2021, 292, 126030. [CrossRef]

8. Alnaqi, A.A.; Moayedi, H.; Shahsavar, A.; Nguyen, T.K. Prediction of energetic performance of a building integrated photovoltaic/thermal system thorough artificial neural network and hybrid particle swarm optimization models. Energy Convers. Manag. 2019, 183, 137-148. [CrossRef]

9. Bukowski, M.; Majewski, J.; Sobolewska, A. Macroeconomic Electric Energy Production Efficiency of Photovoltaic Panels in Single-Family Homes in Poland. Energies 2021, 14, 126. [CrossRef]

10. Hwang, M.-H.; Kim, Y.-G.; Lee, H.-S.; Kim, Y.-D.; Cha, H.-R. A Study on the Improvement of Efficiency by Detection Solar Module Faults in Deteriorated Photovoltaic Power Plants. Appl. Sci. 2021, 11, 727. [CrossRef]

11. Mas'ud, A.A.; Al-Garni, H.Z. Optimum Configuration of a Renewable Energy System Using Multi-Year Parameters and Advanced Battery Storage Modules: A Case Study in Northern Saudi Arabia. Sustainability 2021, 13, 5123. [CrossRef]

12. Idzkowski, A.; Karasowska, K.; Walendziuk, W. Analysis of Three Small-Scale Photovoltaic Systems Based on Simulation and Measurement Data. Proceedings 2020, 51, 19. [CrossRef]

13. Kaewpraek, C.; Ali, L.; Rahman, M.A.; Shakeri, M.; Chowdhury, M.S.; Jamal, M.S.; Mia, M.S.; Pasupuleti, J.; Dong, L.K.; Techato, K. The Effect of Plants on the Energy Output of Green Roof Photovoltaic Systems in Tropical Climates. Sustainability 2021, 13, 4505. [CrossRef]

14. Abdelghany, R.Y.; Kamel, S.; Sultan, H.M.; Khorasy, A.; Elsayed, S.K.; Ahmed, M. Development of an Improved Bonobo Optimizer and Its Application for Solar Cell Parameter Estimation. Sustainability 2021, 13, 3863. [CrossRef]

15. Sohani, A.; Sayyaadi, H. Employing genetic programming to find the best correlation to predict temperature of solar photovoltaic panels. Energy Convers. Manag. 2020, 224, 113291. [CrossRef]

16. Verma, S.; Mohapatra, S.; Chowdhury, S.; Dwivedi, G. Cooling techniques of the PV module: A review. Mater. Today Proc. 2021, 38, 253-258. [CrossRef]

17. Hoseinzadeh, S.; Sohani, A.; Samiezadeh, S.; Kariman, H.; Ghasemi, M.H. Using computational fluid dynamics for different alternatives water flow path in a thermal photovoltaic (PVT) system. Int. J. Numer. Methods Heat Fluid Flow 2021, 31, 1618-1637. [CrossRef]

18. Padilla, J.; Toledo, C.; López-Vicente, R.; Montoya, R.; Navarro, J.-R.; Abad, J.; Urbina, A. Passive Heating and Cooling of Photovoltaic Greenhouses Including Thermochromic Materials. Energies 2021, 14, 438. [CrossRef]

19. Shahsavar, A.; Jha, P.; Arıcı, M.; Estellé, P. Experimental investigation of the usability of the rifled serpentine tube to improve energy and exergy performances of a nanofluid-based photovoltaic/thermal system. Renew. Energy 2021, 170, 410-425. [CrossRef]

20. Salameh, T.; Tawalbeh, M.; Juaidi, A.; Abdallah, R.; Hamid, A.-K. A novel three-dimensional numerical model for PV/T water system in hot climate region. Renew. Energy 2021, 164, 1320-1333. [CrossRef]

21. Popov, R.; Paunkov, N.; Rangelova, V.; Georgiev, A. Study of hybrid thermal system with photovoltaic panels using virtual instruments. Renew. Energy 2020, 154, 1053-1064. [CrossRef]

22. Makkiabadi, M.; Hoseinzadeh, S.; Mohammadi, M.; Nowdeh, S.A.; Bayati, S.; Jafaraghaei, U.; Mirkiai, S.M.; Assad, M.E.H. Energy Feasibility of Hybrid PV/Wind Systems with Electricity Generation Assessment under Iran Environment. Appl. Solar Energy 2020, 56, 517-525. [CrossRef]

23. Sohani, A.; Shahverdian, M.H.; Sayyaadi, H.; Garcia, D.A. Impact of absolute and relative humidity on the performance of mono and poly crystalline silicon photovoltaics; applying artificial neural network. J. Clean. Prod. 2020, 276, 123016. [CrossRef]

24. Memon, S.; Tahir, K.N. Experimental and Analytical Simulation Analyses on the Electrical Performance of Thermoelectric Generator Modules for Direct and Concentrated Quartz-Halogen Heat Harvesting. Energies 2018, 11, 3315. [CrossRef]

25. Memon, S.; Eames, P.C. Solar energy gain and space-heating energy supply analyses for solid-wall dwelling retrofitted with the experimentally achievable U-value of novel triple vacuum glazing. J. Daylighting 2017, 4, 15-25. [CrossRef]

26. Radwan, A.; Katsura, T.; Memon, S.; Abo-Zahhad, E.M.; Abdelrehim, O.; Serageldin, A.A.; Elmarghany, M.R.; Khater, A.; Nagano, K. Development of a new vacuum-based photovoltaic/thermal collector, and its thermal and exergy analyses. Sustain. Energy Fuels 2020, 4, 6251-6273. [CrossRef]

27. Radwan, A.; Katsura, T.; Memon, S.; Serageldin, A.A.; Nakamura, M.; Nagano, K. Thermal and electrical performances of semi-transparent photovoltaic glazing integrated with translucent vacuum insulation panel and vacuum glazing. Energy Convers. Manag. 2020, 215, 112920. [CrossRef]

28. Sohani, A.; Shahverdian, M.H.; Sayyaadi, H.; Samiezadeh, S.; Doranehgard, M.H.; Nizetic, S.; Karimi, N. Selecting the best nanofluid type for A photovoltaic thermal (PV/T) system based on reliability, efficiency, energy, economic, and environmental criteria. J. Taiwan Inst. Chem. Eng. 2021. [CrossRef]

29. Shahverdian, M.H.; Sohani, A.; Sayyaadi, H.; Samiezadeh, S.; Doranehgard, M.H.; Karimi, N.; Li, L.K.B. A dynamic multiobjective optimization procedure for water cooling of a photovoltaic module. Sustain. Energy Technol. Assess. 2021, 45, 101111. [CrossRef]

30. Abadeh, A.; Rejeb, O.; Sardarabadi, M.; Menezo, C.; Passandideh-Fard, M.; Jemni, A. Economic and environmental analysis of using metal-oxides/water nanofluid in photovoltaic thermal systems (PVTs). Energy 2018, 159, 1234-1243. [CrossRef] 
31. Sardarabadi, M.; Hosseinzadeh, M.; Kazemian, A.; Passandideh-Fard, M. Experimental investigation of the effects of using metal-oxides/water nanofluids on a photovoltaic thermal system (PVT) from energy and exergy viewpoints. Energy 2017, 138, 682-695. [CrossRef]

32. Khanjari, Y.; Pourfayaz, F.; Kasaeian, A.B. Numerical investigation on using of nanofluid in a water-cooled photovoltaic thermal system. Energy Convers. Manag. 2016, 122, 263-278. [CrossRef]

33. Chow, T.T.; Pei, G.; Fong, K.F.; Lin, Z.; Chan, A.L.S.; Ji, J. Energy and exergy analysis of photovoltaic-thermal collector with and without glass cover. Appl. Energy 2009, 86, 310-316. [CrossRef]

34. Alnaqi, A.A.; Alsarraf, J.; Al-Rashed, A.A.A.A. Numerical investigation of hydrothermal efficiency of a parabolic dish solar collector filled with oil based hybrid nanofluid. J. Taiwan Inst. Chem. Eng. 2021. [CrossRef]

35. Afrand, M.; Shahsavar, A.; Sardari, P.T.; Sopian, K.; Salehipour, H. Energy and exergy analysis of two novel hybrid solar photovoltaic geothermal energy systems incorporating a building integrated photovoltaic thermal system and an earth air heat exchanger system. Solar Energy 2019, 188, 83-95. [CrossRef]

36. Kim, D.-J.; Kim, D.H.; Bhattarai, S.; Oh, J.-H. Simulation and model validation of the surface cooling system for improving the power of a photovoltaic module. J. Solar Energy Eng. 2011, 133, 041012. [CrossRef]

37. Prudhvi, P.; Sai, P.C. Efficiency improvement of solar PV panels using active cooling. In Proceedings of the 2012 11th International Conference on Environment and Electrical Engineering, Venice, Italy, 18-25 May 2012; pp. 1093-1097.

38. Raval, H.D.; Maiti, S.; Mittal, A. Computational fluid dynamics analysis and experimental validation of improvement in overall energy efficiency of a solar photovoltaic panel by thermal energy recovery. J. Renew. Sustain. Energy 2014, 6, 033138. [CrossRef]

39. Tiwari, G.; Tiwari, S.; Dwivedi, V.; Sharma, S.; Tiwari, V. Effect of water flow on PV module: A case study. In Proceedings of the 2015 International Conference on Energy Economics and Environment (ICEEE), Greater Noida, India, 27-28 March 2015; pp. 1-7.

40. Nižetić, S.; Čoko, D.; Yadav, A.; Grubišić-Čabo, F. Water spray cooling technique applied on a photovoltaic panel: The performance response. Energy Convers. Manag. 2016, 108, 287-296. [CrossRef]

41. Basrawi, F.; Leon, Y.C.; Ibrahim, T.K.; Yusof, M.H.; Razak, A.; Sulaiman, S.A.; Yamada, T. Experimental Analysis on the Effect of Area of Surface Cooling for a Water-Cooled Photovoltaic. MATEC Web Conf. 2018, 225, 01011. [CrossRef]

42. Edaris, Z.L.; Mohammed, M.F.; Saad, M.S.; Yusoff, S.; Tajuddin, M.F.N. Experimental and Simulated Evaluation of Temperature Effect on Panel Efficiency Performance with Front Water Cooling. In Proceedings of the 2018 International Conference on Computational Approach in Smart Systems Design and Applications (ICASSDA), Kuching, Malaysia, 15-17 August 2018; pp. 1-5.

43. Chen, H.; Yang, J.; Zhou, N.; Chen, J.; Zhang, Y. Performance analysis of a high concentrating photovoltaic/thermal system with a water spray cooling device. IOP Conf. Ser. Mater. Sci. Eng. 2019, 556, 012034. [CrossRef]

44. Benato, A.; Stoppato, A. An experimental investigation of a novel low-cost photovoltaic panel active cooling system. Energies 2019, 12, 1448. [CrossRef]

45. Mah, C.-Y.; Lim, B.-H.; Wong, C.-W.; Tan, M.-H.; Chong, K.-K.; Lai, A.-C. Investigating the performance improvement of a photovoltaic system in a tropical climate using water cooling method. Energy Procedia 2019, 159, 78-83. [CrossRef]

46. Sainthiya, H.; Beniwal, N.S. Efficiency enhancement of photovoltaic/thermal module using front surface cooling technique in winter and summer seasons: An experimental investigation. J. Energy Resour. Technol. 2019, 141, 091201. [CrossRef]

47. Tashtoush, B.; Al-Oqool, A. Factorial analysis and experimental study of water-based cooling system effect on the performance of photovoltaic module. Int. J. Environ. Sci. Technol. 2019, 16, 3645-3656. [CrossRef]

48. Luboń, W.; Pełka, G.; Janowski, M.; Pajak, L.; Stefaniuk, M.; Kotyza, J.; Reczek, P. Assessing the Impact of Water Cooling on PV Modules Efficiency. Energies 2020, 13, 2414. [CrossRef]

49. Da Silva, V.O.; Martinez-Bolanos, J.R.; Heideier, R.B.; Gimenes, A.L.V.; Udaeta, M.E.M.; Saidel, M.A. Theoretical and experimental research to development of water-film cooling system for commercial photovoltaic modules. IET Renew. Power Gener. 2021, 15, 206-224. [CrossRef]

50. Javidan, M.; Moghadam, A.J. Experimental investigation on thermal management of a photovoltaic module using water-jet impingement cooling. Energy Convers. Manag. 2021, 228, 113686. [CrossRef]

51. Ervin Solar Company. The Specifications of Yingly YL70C-18b, YL75C-18b, and YL80C-18b Solar Modules. 2021. Available online: http:/ / www.ervinsolar.ir/images/pdf/YL80C-18b.pdf (accessed on 6 April 2021).

52. Mainzer, K.; Killinger, S.; McKenna, R.; Fichtner, W. Assessment of rooftop photovoltaic potentials at the urban level using publicly available geodata and image recognition techniques. Solar Energy 2017, 155, 561-573. [CrossRef]

53. Sohani, A.; Sayyaadi, H. Providing an accurate method for obtaining the efficiency of a photovoltaic solar module. Renew. Energy 2020, 156, 395-406. [CrossRef]

54. Sayyaadi, H. Modeling, Assessment, and Optimization of Energy Systems; Academic Press: London, UK, 2020.

55. Petela, R. Exergy of undiluted thermal radiation. Solar Energy 2003, 74, 469-488. [CrossRef] 